\title{
Production of sugarcane seedlings pre-sprouted in commercial and alternative substrates with by-products of the sugarcane industry
}

\section{Produção de mudas pré-brotadas de cana-de-açúcar em substratos comerciais e alternativos com subprodutos da indústria canavieira}

\author{
Nanda Cristina da Cunha Braga ${ }^{1}$; Eduardo da Costa Severiano ${ }^{2 *}$; \\ Lidiane de Sousa Santos ${ }^{1}$; Aurélio Rúbio Neto²; Tatiana Michlovská Rodrigues³; \\ Jordaanny Danyelly Pereira Lima ${ }^{1}$
}

\begin{abstract}
The sugarcane agro-industry is a major producer of organic waste, which could be used as substrates for production of pre-sprouted sugarcane seedlings aiming at reducing production costs and the sustainability of the sugar and alcohol industry. This study aimed to identify the best position of origin of the bud chip (little portion of stem with one bud) for the production of pre-sprouted seedlings (PSS) of sugarcane and the effects of commercial and alternative substrates containing by-products of the sugarcane industry on the production of sugarcane PSS. For this, a $4 \times 2$ factorial experiment was performed with four substrates: two commercial (TRIMIX ${ }^{\circledR}$ and BIOPLANT ${ }^{\circledR}$ ) and two substrates formulated from sugarcane bagasse and filter cake (SABAFI and SUSBAFI) combined with bud chip from the basal and apical regions. The chemical and physical-hydric properties of the substrates and the development of PSS were evaluated. The substrates evaluated provided contrasting environments for root growth in relation to the physical-hydric and chemical properties. The use of by-products from the sugarcane industry can be added to the formulation of substrates for the production of pre-sprouted sugarcane seedlings, although the commercial substrate TRIMIX ${ }^{\circledR}$ provides superior performance to the seedlings, regardless of the origin position of the bud chip.

Key words: Physical and chemical characteristics. Saccharum sp. Sugar and alcohol residues. Vegetative propagation.
\end{abstract}

\section{Resumo}

A agroindústria canavieira é grande produtora de resíduos orgânicos, que poderiam ser utilizados como substratos na produção de mudas pré-brotadas de cana-de-açúcar visando a redução de custos de produção e a sustentabilidade do setor sucroalcooleiro. Assim, objetivou-se identificar a melhor posição de origem do minirrebolo para a produção de mudas pré-brotadas de cana-de-açúcar (MPB) e os efeitos de substratos comerciais e alternativos com subprodutos da indústria canavieira na produção de MPB de cana-de-açúcar. Para tanto, realizou-se um experimento fatorial $4 \times 2$, sendo quatro substratos: dois comerciais $\left(\right.$ TRIMIX $^{\circledR}$ e BIOPLANT ${ }^{\circledR}$ ) e dois substratos formulados a partir do bagaço da cana e

\footnotetext{
1 Discentes, Curso de Mestrado do Programa de Pós-Graduação em Ciências Agrárias, Instituto Federal Goiano, IF Goiano, Rio Verde, GO, Brasil. E-mail: nandabraga88@gmail.com; lidianesousasantos23@hotmail.com; jordana-17@hotmail.com

2 Profs. Drs., IF Goiano, Programa de Pós-Graduação em Ciências Agrárias, Rio Verde, GO, Brasil. E-mail: eduardo.severiano@ ifgoiano.edu.br; aurelionetorv@gmail.com

3 Pesquisadora, Programa Nacional de Pós-Doutorado da CAPES, IF Goiano, Programa de Pós-Graduação em Ciências Agrárias, Rio Verde, GO, Brasil. E-mail: tatiana_mrodrigues@yahoo.com.br

Author for correspondence
} 
da torta de filtro (SABAFI e SUSBAFI) combinados com minirebolos provenientes da região basal e apical. Avaliaram-se as propriedades químicas e físico-hídricas dos substratos e o desenvolvimento das MPB. Os substratos proporcionaram ambientes de crescimento radicular contrastante em relação às propriedades físicas e químicas. $\mathrm{O}$ uso de subprodutos na formulação de substratos para produção de mudas pré-brotadas de cana-de-açúcar pode ser utilizado, embora o substrato comercial TRIMIX ${ }^{\circledR}$ tenha condicionado desempenho superior às mudas, independentemente da posição de origem do minirrebolo. Palavras-chave: Caracterização física e química. Saccharum $s p$. Resíduos sucroalcooleiro. Propagação vegetativa.

\section{Introduction}

Brazilian sugarcane agribusiness is the largest in the world, with a forecast of an increase of 2.4 million tons in the 2016/17 growing season and an estimated total production of 651.8 million tons sugarcane (Saccharum sp.) (UNIÃO DA INDÚSTRIA DE CANA-DE-AÇÚCAR, 2018). This has led to the generation of new production technologies aimed at increasing productivity and focusing on the preservation of natural resources and the cycling of energy and mass.

The sugarcane industry produces a large amount of organic waste. According to Nogueira and Garcia (2013), each ton of sugarcane produces, among others, about $250 \mathrm{~kg}$ bagasse and $40 \mathrm{~kg}$ filter cake, which have significant risk of pollution when not properly managed. Considering the annual expectation of the Brazilian harvest, the correct destination of these residues assumes agricultural and environmental relevance.

By-products can reduce production costs and improve the institutional image of enterprises to society (NASCIMENTO et al., 2013). In recent years and due to the high costs with mineral inputs, it is possible to use by-products as a conditioning agent of the physical, chemical and biological properties of the soil (ALMEIDA JUNIOR et al., 2011) and as substrates in the production of seedlings.

In this way, new technologies have been developed, such as the propagation system using pre-sprouted seedlings (PSS) of sugarcane derived from individualized buds. This system aims at multiplying sugarcane in tubes, generating seedlings savings, sanity, planting uniformity and also the possibility of taking into the field a smaller volume of material than the conventional crop propagation system (LANDELL et al., 2012; XAVIER et al., 2014). However, scientific studies on this propagation technique are scarce (OLIVEIRA et al., 2018) and still lacking for adequate substrate determination.

The physical properties of the growth medium of seedlings deserve special mention, since chemical properties can be altered with fertilizers and correctives. Porosity and the aeration space should be adequate to favor the gas exchanges and the water holding capacity. In addition, some of this water must be available to the plants and attention must be given to the density of the substrate in the handling of the containers and in the adequate support of plants (FERMINO; KÄMPF, 2012).

The hypotheses tested were: a) the origin of the bud (basal or apical region) affects the seedling quality in the production system of sugarcane PSS and, therefore, constitutes a source of variation in other studies; b) the use of by-products from the sugarcane industry (bagasse and filter cake) as substrates provide similar performance to commercial substrates in the seedling production process. Based on the hypotheses, the goal was to evaluate the best position of origin of the bud and the effects of commercial substrates and those containing by-products from the sugarcane industry on the production of sugarcane PSS, characterizing them initially. 


\section{Material and Methods}

The experiment was conducted in a greenhouse in Rio Verde (state of Goiás, $17^{\circ} 48^{\prime} \mathrm{S}, 50^{\circ} 55^{\prime} \mathrm{W}$ and $748 \mathrm{~m}$ ). For the sugarcane PSS production, we followed the methodology developed by Landell et al. (2012), in a 2x4 factorial completely randomized design with three replications composed of five tubes each.

Two positions in the sugarcane were used to obtain the bud chips (little portion of stem with one bud), basal (lower half) and apical (upper half) of the stem and four substrates: two commercial (TRIMIX $^{\circledR}$ and BIOPLANT ${ }^{\circledR}$ ) and two formulates using by-products from the sugarcane industry
[SABAFI: washed river sand, sugarcane bagasse and filter cake; SUSBAFI: subsurface soil constituted by the B horizon of distroferric Red Latosol (Oxisol) of clayey texture (GONÇALVES et al., 2014), bagasse and cake]. The formulations were prepared in equal volumetric proportions of the constituents (1:1:1).

The physical and chemical characterization of the raw material used in the formulation of the alternative substrates is listed in table 1. Fresh byproducts were initially subjected to the composting process, maintaining moisture and aeration constant, monitored by daily determination of the pile temperature and considered stabilized when internal and external temperatures are balanced.

Table 1. Physical and chemical characterization of raw materials used in formulation of alternative substrates used in pre-sprouted sugarcane seedlings from individual buds.

\begin{tabular}{ccccc}
\hline \multirow{2}{*}{ Attribute } & \multicolumn{3}{c}{ Raw material } \\
\cline { 2 - 5 } & Subsurface soil & Washed sand & Sugarcane bagasse & Filter cake \\
\hline Sand, $\mathrm{kg} \mathrm{kg}^{-1}$ & 326 & 979 & $\mathrm{Nd}$ & $\mathrm{Nd}$ \\
$\mathrm{Silt}, \mathrm{kg} \mathrm{kg}^{-1}$ & 131 & 4 & $\mathrm{Nd}$ & $\mathrm{Nd}$ \\
$\mathrm{Clay}_{\mathrm{kg} \mathrm{kg}}$ & 543 & 17 & $\mathrm{Nd}$ & $\mathrm{Nd}$ \\
$\mathrm{SiO}_{2}, \mathrm{~kg} \mathrm{~kg}^{-1}$ & 91 & $\mathrm{Nd}$ & $\mathrm{Nd}$ & $\mathrm{Nd}$ \\
$\mathrm{Al}_{2} \mathrm{O}_{3}, \mathrm{~kg} \mathrm{~kg}^{-1}$ & 191 & $\mathrm{Nd}$ & $\mathrm{Nd}$ & $\mathrm{Nd}$ \\
$\mathrm{Fe}_{2} \mathrm{O}_{3}, \mathrm{~kg} \mathrm{~kg}^{-1}$ & 211 & $\mathrm{Nd}$ & $\mathrm{Nd}$ & $\mathrm{Nd}$ \\
$\mathrm{Ki}$ & 0.80 & $\mathrm{Nd}$ & $\mathrm{Nd}$ & $\mathrm{Nd}$ \\
$\mathrm{Kr}$ & 0.47 & $\mathrm{Nd}$ & $\mathrm{Nd}$ & $\mathrm{Nd}$ \\
$\mathrm{PD}, \mathrm{kg} \mathrm{dm}^{-3}$ & 2838 & 2652 & $\mathrm{Nd}$ & $\mathrm{Nd}$ \\
$\mathrm{WBD}, \mathrm{kg} \mathrm{dm}^{-3}$ & 1141 & 1530 & 235 & 835 \\
$\mathrm{DBD}, \mathrm{kg} \mathrm{dm}^{-3}$ & 906 & 1361 & 75.96 & 484.15 \\
$\mathrm{pH}\left(\mathrm{H}_{2} \mathrm{O}\right)$ & 7.18 & 9.93 & 6.98 & 7.53 \\
E.C., $\mathrm{mS} \mathrm{cm}^{-1}$ & 0.05 & 0.30 & 0.05 & 2.0 \\
$\mathrm{C} / \mathrm{N} \mathrm{ratio}$ & $\mathrm{Nd}$ & $\mathrm{Nd}$ & 95 & 25 \\
\hline
\end{tabular}

Attributes determined according to EMBRAPA (2011): Soil texture: Sand (2.00-0.05 mm), silt (0.05-0.002 mm) and clay $(<0.002$ $\mathrm{mm}$ ), determined by the pipette method. Content of $\mathrm{SiO}_{2}, \mathrm{Al}_{2} \mathrm{O}_{3}$ and $\mathrm{Fe}_{2} \mathrm{O}_{3}$ from the sulfuric attack; $\mathrm{Ki}$ : molecular ratio ( $\mathrm{SiO} /$ $\left.\mathrm{Al}_{2} \mathrm{O}_{3}\right)$; $\mathrm{Kr}$ : molecular ratio $\mathrm{SiO} 2:\left(\mathrm{Al}_{2} \mathrm{O}_{3}+\mathrm{Fe}_{2} \mathrm{O}_{3}\right)$; PD: Particle Density; Attributes determined according to MAPA-IN n. 17: WBD: Wet bulk density; DBD: Dry bulk density; $\mathrm{pH}\left(\mathrm{H}_{2} \mathrm{O}\right)$ (dimensionless); E.C.: electrical conductivity; Nd: non-determined.

The commercial substrates were made of the following raw materials, according to the manufacturer: - TRIMIX ${ }^{\circledR}$ : rice husk, vermiculite and coconut fiber; - BIOPLANT ${ }^{\circledR}$ : pine bark, coconut fiber, vermiculite and nutrients. After the commercial and formulated substrates were obtained, three samples were naturally air dried for 72 hours, aiming at the characterization of the plant growth environment. 
The physical evaluation of substrates was performed in triplicate, following the normative instructions (MAPA-IN) defined by the Ministry of Agriculture, Livestock and Supply. The wet bulk density (WBD) was determined through the self-compacting method (BRASIL, 2008). After this procedure, samples were taken to an oven at $65^{\circ} \mathrm{C}$ to constant weight (BRASIL, 2007) and the values were used to determine the dry bulk density (DBD).

In order to determine the physical-hydric attributes, samples of substrates were placed in PVC cylinders, $4 \mathrm{~cm}$ in diameter and $5 \mathrm{~cm}$ in height, and saturated with distilled water for 24 hours and subjected to 10 and $100 \mathrm{hPa}$ tensions (DE BOODT; VERDONCK, 1972; BRASIL, 2008). The following parameters were determined: - total porosity (TP), considering the volumetric moisture present in the saturated samples (tension $0 \mathrm{hPa}$ ); - Water retention curve (WRC), considering the moisture present in the samples at $10 \mathrm{hPa}$; Aeration space (AS) represents the difference between the total porosity and the moisture at 10 $\mathrm{hPa}$ and; - Remaining water (RW), the volume of water retained at $100 \mathrm{hPa}$.

The particle size analysis was performed by mechanical agitation of the air-dried substrates for five minutes using the following mesh sizes: 3.35 - $2.00-1.00-0.50-0.106 \mathrm{~mm}$. With the material retained in each sieve, the percentage of the fraction was determined according to Zorzeto et al. (2014). The chemical characterization of the substrates was also performed in triplicate, according to MAPA (BRASIL, 2007). To this end, a $60 \mathrm{~mL}$ aliquot measured by substrate density in $300 \mathrm{~mL}$ distilled water was taken to a Wagner's shaking machine at $40 \mathrm{rpm}$ for one hour. Subsequently, the solution was filtered and then read the $\mathrm{pH}$ and electrical conductivity (EC).

The bud chip used for the production of seedlings were of the CTC-4 variety, obtained under conditions of plant cane of 12 months, at the Usina Boa Vista, located in the municipality of Quirinópolis, state of Goiás. After the cut of bud chip, manual selection was performed in order to eliminate buds with mechanical damage or with symptoms of pathogen attack, besides treatment with fungicide. Then, the bud chips were weighed and placed in sprouting boxes, using substrate BIOPLANT $^{\circledR}$. During a period of 15 days, the budding speed index (BSI) was analyzed according to the methodology of Gírio et al. (2015).

The obtained seedlings were subjected to leaf pruning and transplanted into $290 \mathrm{~cm}^{3}$ tubes containing the substrates according to the described treatments, filled by self-compaction (BRASIL, 2008). They received the cultural practices during the whole development and fertilizers used (the following amounts were added to each $100 \mathrm{dm}^{3}$ of substrate: $200 \mathrm{~g}$ of potassium chloride $(58 \%$ of $\left.\mathrm{K}_{2} \mathrm{O}\right), 300 \mathrm{~g}$ of ammonium sulfate $(20 \% \mathrm{~N}$ and $20 \%$ S), 200g of Yoorin thermophosphate $\left(16 \%\right.$ of $\mathrm{P}_{2} \mathrm{O}_{5}$ and micronutrients), $5 \mathrm{~g}$ of Forthcote Minipril ${ }^{\circledR}$ $\left(19 \% \mathrm{~N}, 06 \% \mathrm{~K}_{2} \mathrm{O}, 10 \% \mathrm{P}_{2} \mathrm{O}_{5}\right.$ and $3.5 \% \mathrm{~S}$, liberated for about three months) and $5 \mathrm{~g}$ Forthcote Plus ${ }^{\circledR}$ $\left(15 \% \mathrm{~N}, 9 \% \mathrm{~K}_{2} \mathrm{O}, 12 \% \mathrm{P}_{2} \mathrm{O}_{5}, 1.3 \% \mathrm{Mg}, 6 \% \mathrm{~S}\right.$, $0.05 \% \mathrm{Cu}, 0.46 \% \mathrm{Fe}, 0.06 \% \mathrm{Mn}$ and $0.02 \% \mathrm{Mo}$, with release around five months) in seedlings were added as recommended by Landell et al. (2012).

The seedlings were maintained in the greenhouse for 30 days and in the sequence, taken to the benches in full sun for another 35 days for to the full sun area.

During this period, leaf pruning and fertilization were performed every 14 days with calcium nitrate and monoammonium phosphate. The cut material was used to determine the dry mass of leaf pruning (DMLP).

After completion the production stages, seedlings were subjected to the last pruning and to assessments of plant height from the base to the top, number of leaves and tillers. Then, they were collected, washed with water to remove the 
substrate and separated into shoots and roots, which were dried in a forced circulation oven at $65^{\circ} \mathrm{C}$ for 72 hours to obtain dry mass of shoots (DMS) and roots (DMR).

The results of the attributes of the substrates and the productive variables of sugarcane PSS were subjected to analysis of variance and Tukey's test $(\mathrm{p}<0.05)$ whenever significant, using SISVAR software (FERREIRA, 2011).

\section{Results and Discussion}

The substrates evaluated showed differences in particle size, with a predominance of fine fractions, mainly between 0.5 and $1.00 \mathrm{~mm}$ for TRIMIX $^{\circledR},<$ $1.00 \mathrm{~mm}$ for BIOPLANT ${ }^{\circledR}$ and SABAFI, while for SUSBAFI, fractions $<0.5 \mathrm{~mm}$ (Figure 1). For the formulated substrates, the results are related to the greater proportion and density of fine raw materials (sand, soil and cake), in relation to bagasse, which has low density (Table 1).

Figure 1. Particle size distribution of commercial substrates (TRIMIX ${ }^{\circledR}$ and BIOPLANT ${ }^{\circledR}$ ) and based on subsurface soil, sugarcane bagasse and filter cake (SUSBAFI) and sand, sugarcane bagasse and filter cake (SABAFI) formulated at proportion of 1:1:1. Mean values followed by different uppercase letters between substrates and lowercase letters between particle size classes are significantly different.

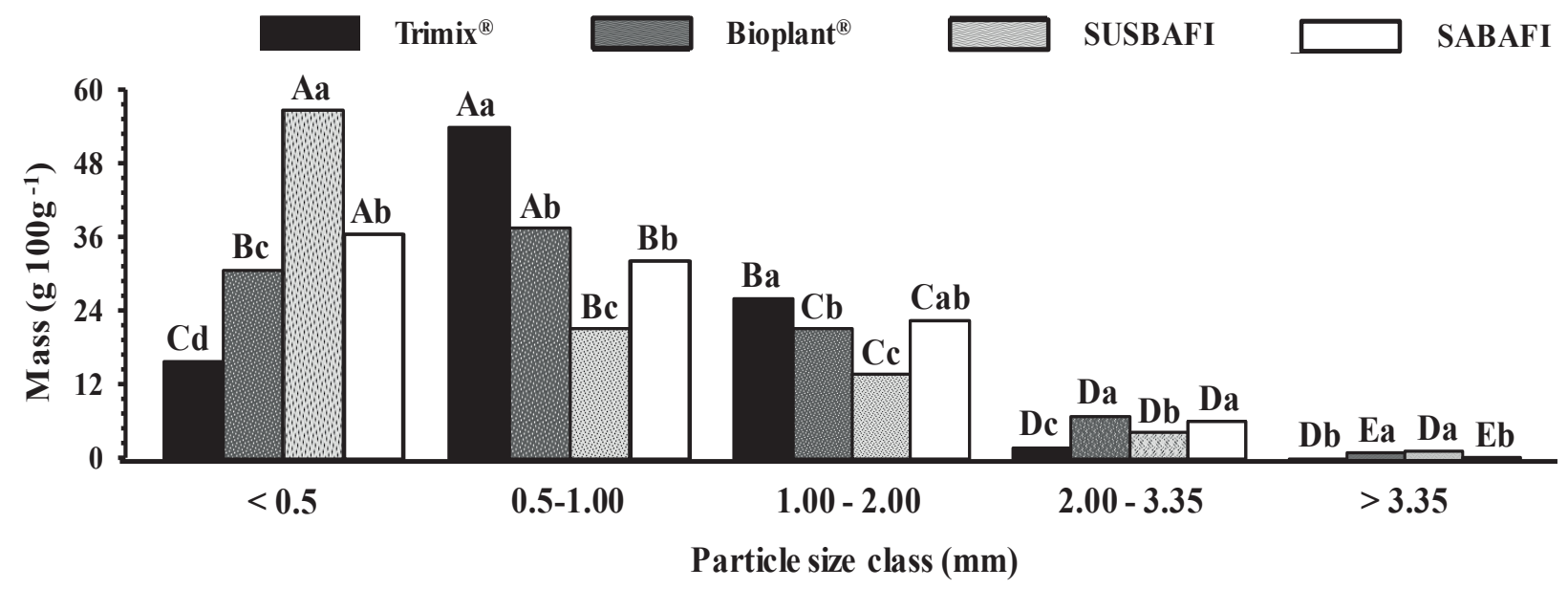

The particle size is important in the physical quality of the material, with significant influence on the arrangement of particles and the porous space. It should be noted that particles with larger diameter are associated with the formation of aeration pores, whereas particles of smaller diameter are responsible for the formation of micropores, occupied by water (ZANETTI et al., 2003).

The behavior of the other physical-hydric attributes of the substrates may have been influenced by the particle size (Figure 1), and by the composition of the raw materials used (Table 1). In this sense, WBD (Figure 2a) indicates SABAFI as the highest value material (approximately $1100 \mathrm{~kg} \mathrm{~m}^{-3}$ ), followed by SUSBAFI, TRIMIX ${ }^{\circledR} \mathrm{e}$ BIOPLANT $^{\circledR}$ (between 400 and $800 \mathrm{~kg} \mathrm{~m}^{-3}$ ).

Similar behavior was found for DBD (Figure $2 b)$. Therefore, the presence of materials of mineral origin and with fine particle size $(<2.0$ $\mathrm{mm}$ ) contributed for the elevation of the substrate density values. On the other hand, commercial substrates present considerable proportions of fine particles with low density (Figure 2). These results corroborate Zorzeto et al. (2014) on substrates based on coconut fiber, pine bark and rice husk. 
Figure 2. Physical characterization [(a) Wet and (b) dry density] of commercial substrates (TRIMIX ${ }^{\circledR}$ and BIOPLANT ${ }^{\circledR}$ ) and based on subsurface soil, sugarcane bagasse and filter cake (SUSBAFI) and sand, sugarcane bagasse and filter cake (SABAFI) formulated at proportion of 1:1:1. In each variable, mean values followed by different letters are significantly different.

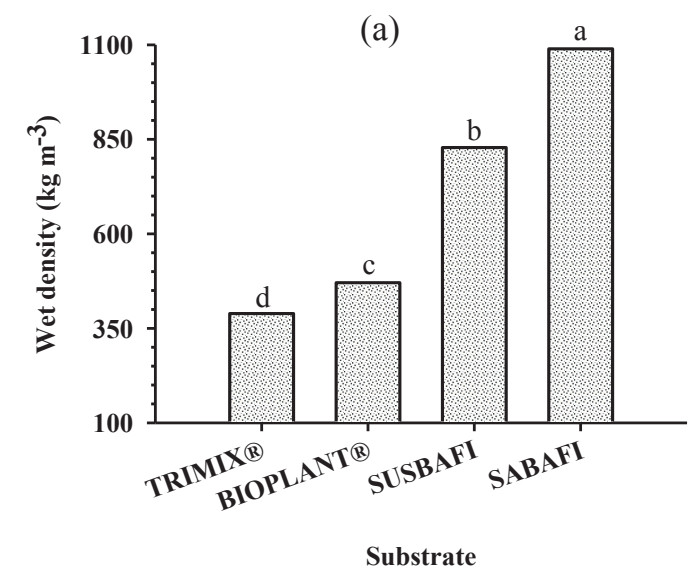

The high density of substrates of SABAFI and SUSBAFI, according to Severiano et al. (2013), is due to lower intra-microaggregate porosity in sand fractions, with an inverse relationship to the clay content in Oxisols of the Cerrado in Brazil. In addition, even substrates formulated with $2 / 3$ of sugarcane by-products of organic origin had their densities strongly influenced by sand and subsurface soil.

The commercial substrates TRIMIX $^{\circledR}$ and BIOPLANT $^{\circledR}$ presented higher values of total porosity (approximately $0.78 \mathrm{~m}^{3} \mathrm{~m}^{-3}$ ), inversely proportional to the density, since this attribute corresponds to the volume not occupied by solid fractions. In turn, the formulations SUSBAFI and SABAFI showed porosity, approximately 24\% lower than the commercial ones (Figure 3a).

The formulated substrates presented TP values lower than $0.60 \mathrm{~m}^{3} \mathrm{~m}^{-3}$ (Figure 3a), which may impair the development of pre-sprouted sugarcane seedlings, since values from 0.75 to $0.90 \mathrm{~m}^{3} \mathrm{~m}^{-3}$ are considered optimal for seedling production, for better aeration, water infiltration and drainage (LEMAIRE, 1995).

As for WRC $(>10 \mathrm{hPa})$, SUSBAFI had a larger volume $\left(0.50 \mathrm{~m}^{3} \mathrm{~m}^{-3}\right)$, followed by BIOPLANT ${ }^{\circledR}$ $\left(0.43 \mathrm{~m}^{3} \mathrm{~m}^{-3}\right)$, TRIMIX ${ }^{\circledR}\left(0.38 \mathrm{~m}^{3} \mathrm{~m}^{-3}\right)$ and SABAFI $\left(0.35 \mathrm{~m}^{3} \mathrm{~m}^{-3}\right)$ (Figure $3 \mathrm{~b}$ ). This is due to the clay particles present in the subsurface soil used in its formulation (Table 1).

Evaluating the water retention in Oxisols of the Cerrado and, therefore, similar to the soil material used in the SUSBAFI formulation, Severiano et al. (2013) have shown that water holding increases according to the increase in clay content. This is due to the increase of textural pores (intra-aggregate pores), the main factor associated with water holding in soils of the Cerrado region.

The intermediate behavior of the commercial substrates was probably related to vermiculite, which, after thermal expansion, acquires a high water holding capacity (FERRAZ et al., 2005) (Figure 3b). These results suggest that the incorporation of subsurface soil into substrates formulated from byproducts from the sugarcane industry can minimize the deleterious effects of water stress on the development of sugarcane seedlings. On the other hand, it is emphasized the need for correct irrigation management of seedlings produced in substrates with less water retention (TRIMIX ${ }^{\circledR}$ and SABAFI). 
Figure 3. Physical-hydric characterization [(a) Total porosity: $0 \mathrm{hPa}$, (b) water holding capacity: $10 \mathrm{hPa}$, (c) remaining water $<100 \mathrm{hPa}$ and $(\mathrm{d})$ aeration space between 0 and $10 \mathrm{hPa}$ ] of commercial substrates (TRIMIX ${ }^{\circledR}$ and BIOPLANT ${ }^{\circledR}$ ) and based on subsurface soil, sugarcane bagasse and filter cake (SUSBAFI) and sand, sugarcane bagasse and filter cake (SABAFI) formulated at proportion of 1: 1: 1. In each variable, mean values followed by different letters are significantly different.
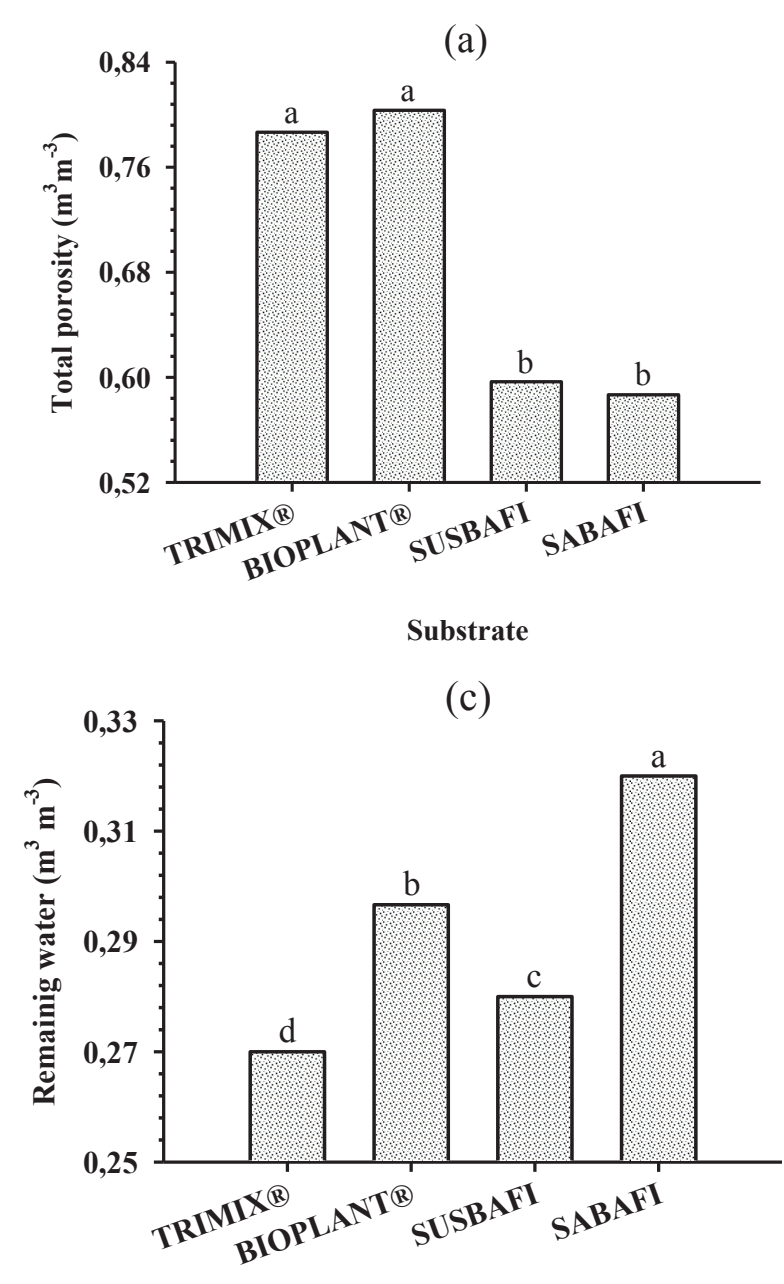

Substrate

SABAFI presented the highest value of RW $(0.32$ $\left.\mathrm{m}^{3} \mathrm{~m}^{-3}\right)$, followed by BIOPLANT ${ }^{\circledR}\left(0.30 \mathrm{~m}^{3} \mathrm{~m}^{-3}\right)$, SUSBAFI $\left(0.28 \mathrm{~m}^{3} \mathrm{~m}^{-3}\right)$ and TRIMIX ${ }^{\circledR}\left(0.26 \mathrm{~m}^{3} \mathrm{~m}^{-3}\right)$ (Figure 3c). Considering that this water is retained under high matric potential, which limits the access to the plants, it is reinforced the caution regarding the water replenishment in these substrates, and also the necessity of studies on irrigation of sugarcane PSS.

The AS ranged from 0.08 to $0.40 \mathrm{~m}^{3} \mathrm{~m}^{-3}$ (Figure $3 \mathrm{~d}$ ), and the ideal value for the cultivation

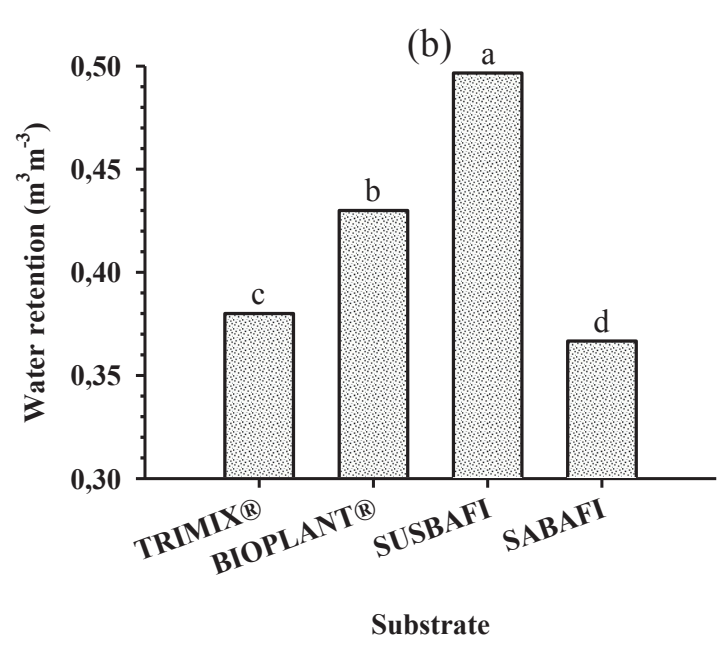

(d)

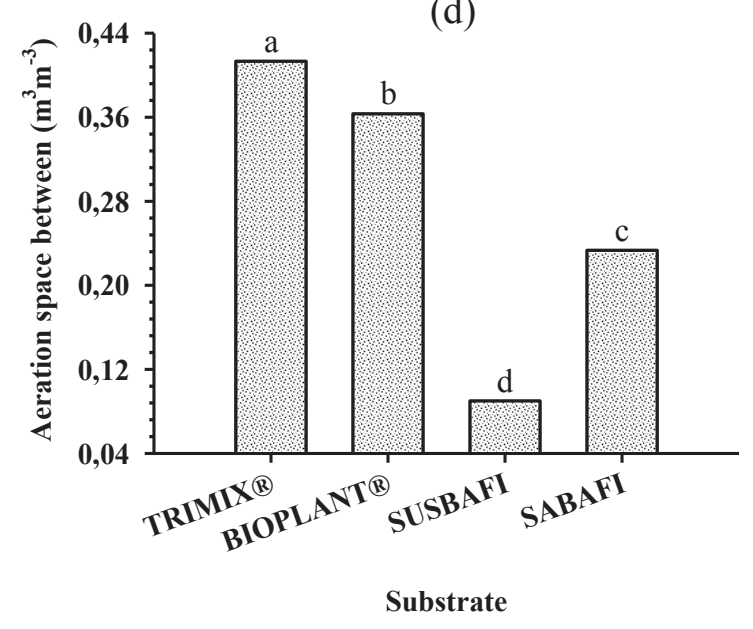

lies between 0.20 and $0.30 \mathrm{~m}^{3} \mathrm{~m}^{-3}$ (DE BOODT; VERDONCK, 1972). The lowest value was obtained for the substrate SUSBAFI $\left(0.08 \mathrm{~m}^{3} \mathrm{~m}^{-3}\right)$. In turn, SABAFI with $0.25 \mathrm{~m}^{3} \mathrm{~m}^{-3}$ is within the ideal range for cultivation.

Higher values of AS were obtained in commercial substrates TRIMIX ${ }^{\circledR}$ and BIOPLANT ${ }^{\circledR}\left(0.40 \mathrm{~m}^{3} \mathrm{~m}^{-3}\right.$ and $0.36 \mathrm{~m}^{3} \mathrm{~m}^{-3}$, respectively). These values, which were higher than the reference values, provide larger space for rooting and exploitation for higher plant growth. However, this characteristic should be 
evaluated in plants of interest (e.g. sugarcane), since they may also promote lower substrate-root contact, and absorption of water and nutrients.

Besides the differences in physical-hydric attributes, the chemical properties were also affected by the substrates (Figure 4), with $\mathrm{pH}$ reduction
(Figure 4a) and increase in electrical conductivity (Figure 4b) as a result of planting fertilization. For $\mathrm{pH}$, the values obtained are consistent with those found by Ludwig et al. (2014) and can be used in cultivation without impairing the nutrient availability of the medium.

Figure 4. Chemical characterization [(a) $\mathrm{pH}$ and (b) electrical conductivity] of commercial substrates (TRIMIX ${ }^{\circledR}$ and BIOPLANT ${ }^{\circledR}$ ) and based on subsurface soil, sugarcane bagasse and filter cake (SUSBAFI) and sand, sugarcane bagasse and filter cake (SABAFI) formulated at proportion of 1: 1: 1. Mean values followed by different uppercase letters between fertilization times (before and after) and lowercase letters between substrates are significantly different.

$\square$ Before fertilization

(a)

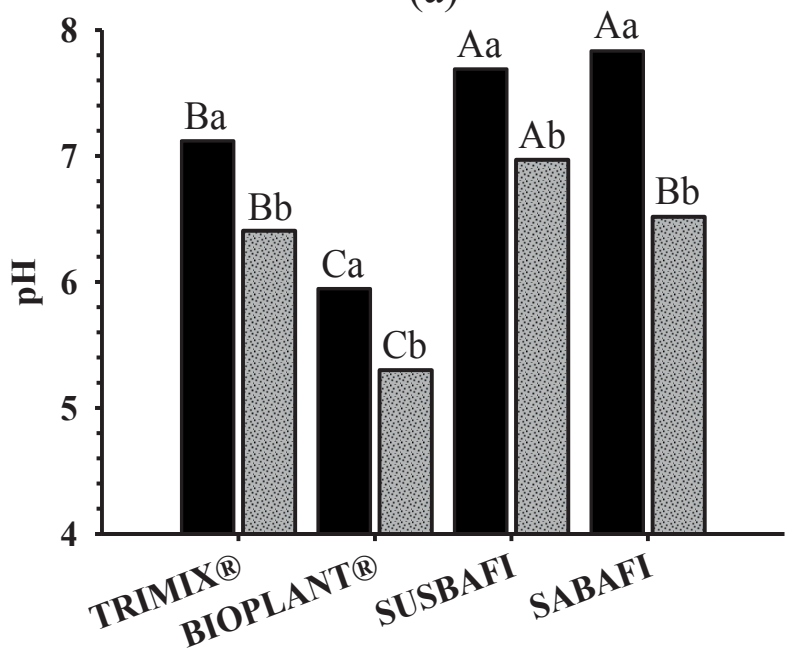

Substrate

Considering the theoretical optimum $\mathrm{pH}$ in water of substrates between 5.2 and 6.3, according to Abad et al. (1993), BIOPLANT ${ }^{\circledR}$, followed by TRIMIX ${ }^{\circledR}$, both after fertilization fell within this range. Thus, it is expected that, from the point of view of acidity, commercial substrates can contribute to the better development of PSS of sugarcane, which, according to Kämpf (2000), is associated with both nutrient availability and the biology of the substrate microorganisms.

The $\mathrm{pH}\left(\mathrm{H}_{2} \mathrm{O}\right)$ close to 7.0 verified in the substrates formulated with by-products from sugarcane industry can lead to a remarkable reduction in the availability of micronutrients. In agreement with De

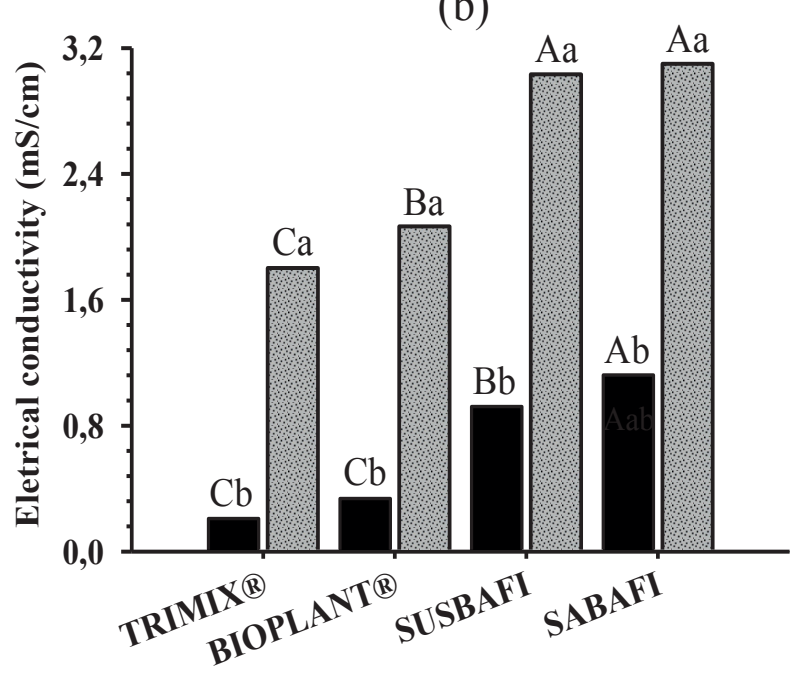

Substrate

Boodt and Verdonck (1972), inadequate $\mathrm{pH}$ values can affect the growth and development of plants, especially under excessive acidity.

The electrical conductivity of the substrate had an opposite behavior, in which the fertilization promoted a considerable increase (Figure 4b). According to Santana et al. (2007), sugarcane is considered moderately sensitive to salinity and its production can be reduced by $50 \%$ with values around $10.4 \mathrm{mS} \mathrm{cm}^{-1}$ in the soil. Likewise, Martínez (2002) considers values higher than $3.5 \mathrm{mS} \mathrm{cm}^{-1}$ in substrates as very high and can compromise the growth of seedlings. 
We observed that bud chips of the basal region are larger because they are physiologically older and, thus, subjected to greater accumulation of photoassimilates (Figure 5a). However, the greater accumulation of organic reserves did not imply higher budding. For the sprouting rate (Figure $5 \mathrm{~b}$ ) and the sprouting percentage (Figure 5c), the bud chips taken from the apex stood out slightly compared to those of basal origin.

Figure 5. Characterization of sugarcane bud chip used in pre-sprouted seedlings production [(a) Dry mass, (b) sprouting rate and (c) sprouting percentage]. Mean values followed by different letters are significantly different.

(a)

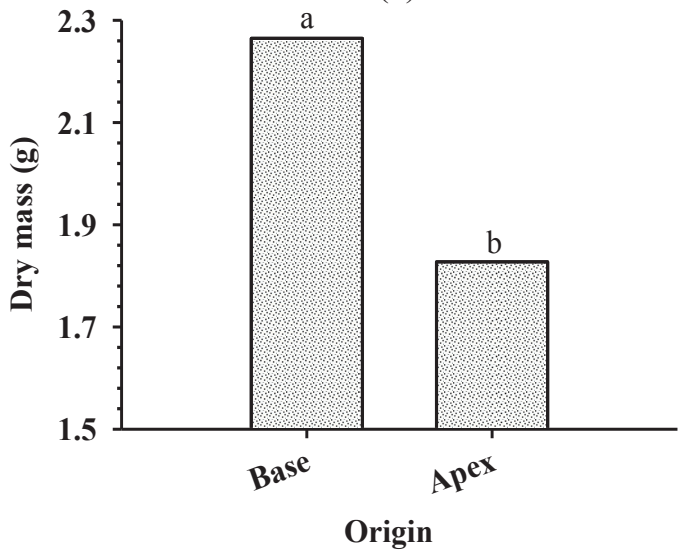

(b)

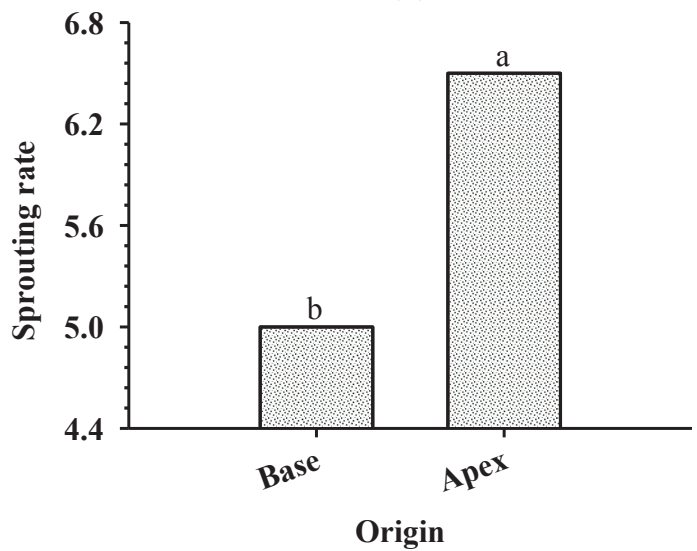

(c)

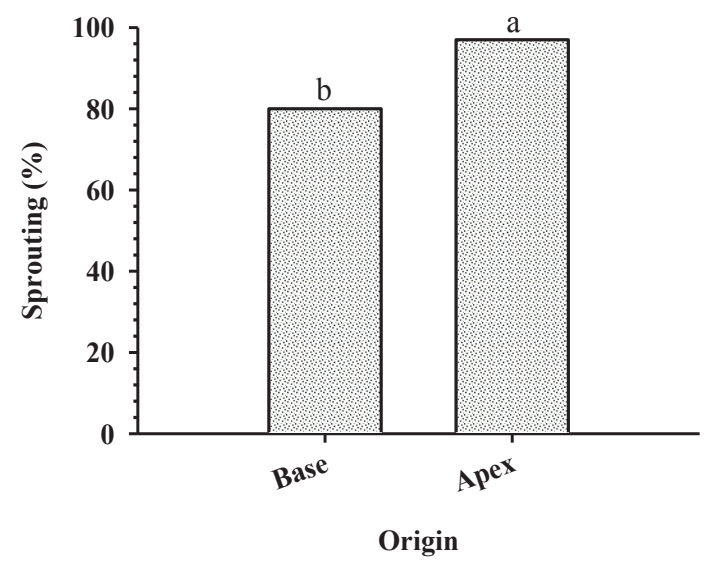

In conventional sugarcane plating systems, it is used stems cuttings (are called setts) with each sett contains approximately three buds basal crossed with apex setts, which the basal stems are most development. For the PSS system of sugarcane propagation, the results in Figure 5 suggest an inverse behavior since apical buds provided greater sprouting in relation to the basal ones. It is considered, therefore, that the buds from the apex reached physiological maturity and, because they were subjected to the shortest exposure to deleterious agents in the field (e.g., drought, pest attack), they were more vigorous.

Another factor that influences the sprouting of buds is the apical dominance exerted by the bud at the apex. Sugarcane produces auxins that move from the top to the base, inhibiting the sprouting of lateral buds and, thus, buds near the apex sprout more quickly because they have more of this hormone 
(SEGATO et al., 2006). Therefore, the advantage of using conventional sugarcane seedlings is due to the amount of sucrose reserve in the stem, which is eliminated in the PSS when cutting the bud chip and eliminating the internodes, thus standing out, in this system, the quality of the bud. Nevertheless, it is necessary to verify if the better performance at sprouting of seedlings obtained from apical buds will imply higher quality seedlings at the end of the productive process.

Thus, in table 2, the analysis of variance for the productive variables of the pre-budded seedlings at the end of the process detected no significance regarding the origin position of the bud chip, except for the dry mass of roots (DMR), which had interaction with the substrate.

Table 2. Analysis of variance, overall means and coefficients of variation for productive variables of pre-sprouted sugarcane seedlings from individual buds according to the type of substrate and origin position of the bud.

\begin{tabular}{ccccccc}
\hline \multirow{2}{*}{ Source of variation } & \multicolumn{6}{c}{ Mean square } \\
\cline { 2 - 6 } & $\mathrm{DMS}^{(1)}$ & $\mathrm{DMLP}^{(2)}$ & $\mathrm{DMR}^{(3)}$ & $\mathrm{PHe}^{(4)}$ & $\mathrm{NL}^{(5)}$ & $\mathrm{NT}^{(6)}$ \\
\hline Substrate (S) & $0.047^{* *}$ & $0.131^{* *}$ & $0.005^{* *}$ & $7.230^{* *}$ & $8.686^{* *}$ & $0.295^{\text {ns }}$ \\
Position (P) & $0.009^{\text {ns }}$ & $0.010^{\text {ns }}$ & $0.004^{* *}$ & $0.429^{\text {ns }}$ & $0.735^{\text {ns }}$ & $0.375^{\text {ns }}$ \\
S x P & $0.003^{\text {ns }}$ & $0.012^{\text {ns }}$ & $0.003^{* *}$ & $0.377^{\text {ns }}$ & $2.162^{\text {ns }}$ & $0.433^{\text {ns }}$ \\
Residue & 0.003 & 0.009 & 0.001 & 0.583 & 2.130 & 0.325 \\
\hline Overall mean & 0.62 & 0.80 & 0.23 & 14.87 & 11.36 & 2.49 \\
C.V. & 9.25 & 11.79 & 12.88 & 5.14 & 12.85 & 22.88 \\
\hline
\end{tabular}

${ }^{(1)}$ Dry mass of shoots; (2) Dry mass of leaf pruning; ${ }^{(3)}$ Dry mass of roots; ${ }^{(4)}$ Plant height; ${ }^{(5)}$ Number of leaves; ${ }^{(6)}$ Number of tillers.

${ }^{n s}$ Non-significant. ** Significant at $\mathrm{p}<0.01$, by F-test.

On the other hand, the substrates affected the plant growth in almost all the analyzed variables, except for tillering, with a mean value of 2.5 tillers per plant, result probably related to the high variability of this attribute, observed by the coefficient of variation $(22.88 \%)$. This may be associated to the evaluated variety or to the variability of the data.

Although there is a difference in the early seedling growth (Figure 5), after the 60-day seedling production period, these differences were suppressed. It should be noted, therefore, that the sprouting phase, equivalent to $25 \%$ of the seedling cycle (15 days), reflects the physiological and phytosanitary balance of the bud chip.

After removal of the non-sprouted buds, the seedlings developed uniformly as to the origin position, and the development was affected by the substrate used in their growth medium. This is because, after transplanting the seedlings, growth is regulated exclusively by substrate-plantatmosphere relationships, with dependence on roots for water and nutrient uptake and on shoots for photoassimilate production.

There was a difference in the growth of seedlings according to the substrates evaluated. This is positive to obtain uniform sugarcane fields, which does not demonstrate the need for stratification of the bud origin position for seedling production, and therefore, the sugarcane stem is completely used in PSS.

Although not evaluated the origin of the sugarcane bud, Gírio et al. (2015) investigated three levels of reserves in the buds and showed bud chips with greater amount of reserves with higher production potential when compared to seedlings from smaller buds, demonstrating that the organic reserve of the bud chips has a direct influence on the sprouting and initial growth of the plant. 
Considering the phenology of sugarcane, stems of a ratoon crop have different ages according to the tillering cycle of the crop; the first tillers are subjected to biomass accumulation for a longer time than younger tillers. In the same stem, the apical buds are smaller than those at the base, but within the same clump, it is possible that setts in a primary tiller have a larger organic reserve, compared to the setts of the basal region of stems that were developed posteriorly.

Importantly, with stems of different ages in the same clump of sugarcane, we cannot draw comparisons to the work of Gírio et al. (2015), since buds of the basal and apical regions distributed in the three reserve levels are expected. It is suggested (although all the bud chips have the same length, diameter and consequently organic reserves varies according to age and position in stem), therefore, that the age of the bud has more relevance in sprouting and, once sprouted, what differentiates the development is the amount of organic reserve, given its influence on cellular differentiation and, consequently, plant growth.

Moreover, for all growth and development attributes, the TRIMIX ${ }^{\circledR}$ substrate stood out in relation to the other substrates, due to superior or similar behavior. This substrate provided higher dry mass of shoots (Figure 6b) and plant height (Figure 6d), higher dry mass of leaf pruning along with the BIOPLANT ${ }^{\circledR}$ substrate (Figure 6a) and higher number of leaves, together with BIOPLANT ${ }^{\circledR}$ and SUSBAFI (Figure 6e). In relation to the dry mass of roots (Figure $6 \mathrm{c}$ ), the interaction between substrate and origin position presented higher results for TRIMIX $^{\circledR}$ and SABAFI for bud chips of the apical region in relation to the basal.

The superiority of the TRIMIX ${ }^{\circledR}$ substrate for the growth of pre-sprouted sugarcane seedlings found herein (Figure 6) should be understood through its physical-hydric and chemical attributes. Despite the lowest values of density (Figure 2) and water holding lower than SUSBAFI (Figure 3b), pH (Figure 4a) and EC (Figure 4b), the TRIMIX ${ }^{\circledR}$ substrate had the largest aeration space (Figure $3 \mathrm{~d}$ ).

The greater retention of water in a substrate is essential for proper plant growth and development. Although presenting these attributes inferior to SUSBAFI, the management of leaf pruning and irrigation, defined by Landell et al. (2012), is sufficient to suppress eventual deficiencies in water retention by the substrate, leading to mitigation of the effect of water retention.

On the other hand, Ludwig et al. (2014) pointed out that the growth of plants at $\mathrm{pH}$ around 7.0 promotes nutritional disorders in terms of micronutrient deficiency (mainly iron), while at $\mathrm{pH}$ below 5.0, plants presented toxic levels of manganese, which lead to lower phytomass production. In this context, the $\mathrm{pH}$ of TRIMIX ${ }^{\circledR}$ stands out, around 6.0 (Figure 4a).

In contrast, the large aeration space (Figure 3d) may have contributed to the greater rooting and, consequently, exploitation of the substrate volume in the container. Because it is a species with fasciculated roots, it is suggested that the larger empty space after irrigation water drainage may have stimulated root growth, as shown in Figure 6c.

Considering the importance of pruning in PSS management, seedlings produced in the TRIMIX ${ }^{\circledR}$ substrate surpassed those produced in the substrates formulated in the DMLP, with a performance similar to the seedlings produced in BIOPLANT ${ }^{\circledR}$ (Figure 6a), which in turn presented AS slightly lower than TRIMIX $^{\circledR}$.

The pre-sprouted seedling consists of the aerial part and the root system, for purposes of sugarcane production. In this sense, seedlings with higher dry mass of aerial part (DMAP) and root (DMR), such as those in the substrate TRIMIX $^{\circledR}$, correspond to plants with greater vigor for initial seedling growth in the field. This fact is of utmost importance when considering the main sugarcane planting season in the south-central region of the country, February and March, characterized by the end of the rainy season. 
Figure 6. Productive variables of pre-sprouted sugarcane seedlings from individual buds grown on commercial substrates (TRIMIX ${ }^{\circledR}$ and BIOPLANT ${ }^{\circledR}$ ) and produced using by-products from the sugarcane industry [subsurface soil, sugarcane bagasse and filter cake (SUSBAFI) and sand, sugarcane bagasse and filter cake (SABAFI) formulated at a ratio of 1: 1: 1. Mean values followed by different uppercase letters between origin positions and lowercase letters between substrates are significantly different.

(a)

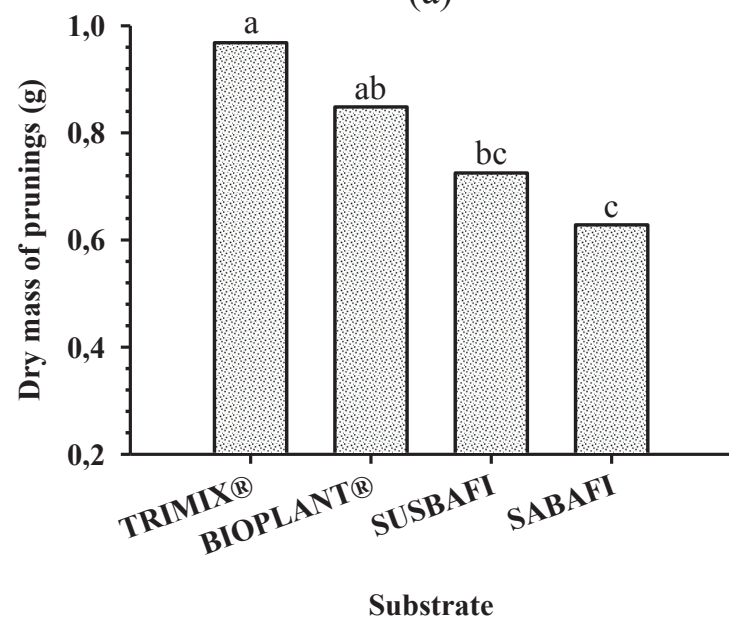

(c)

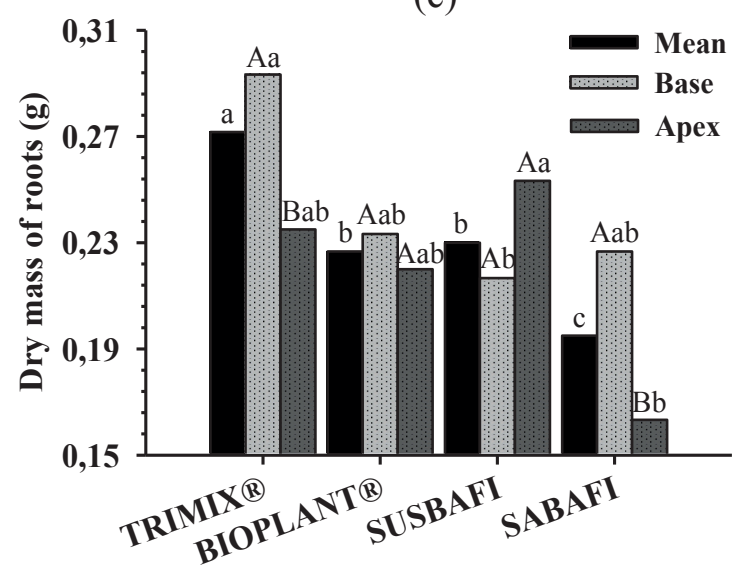

Substrate (b)

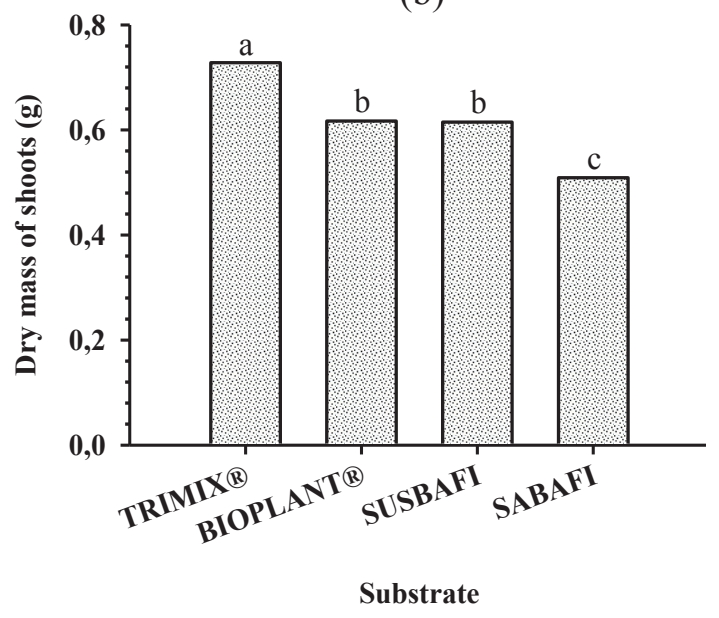

(d)

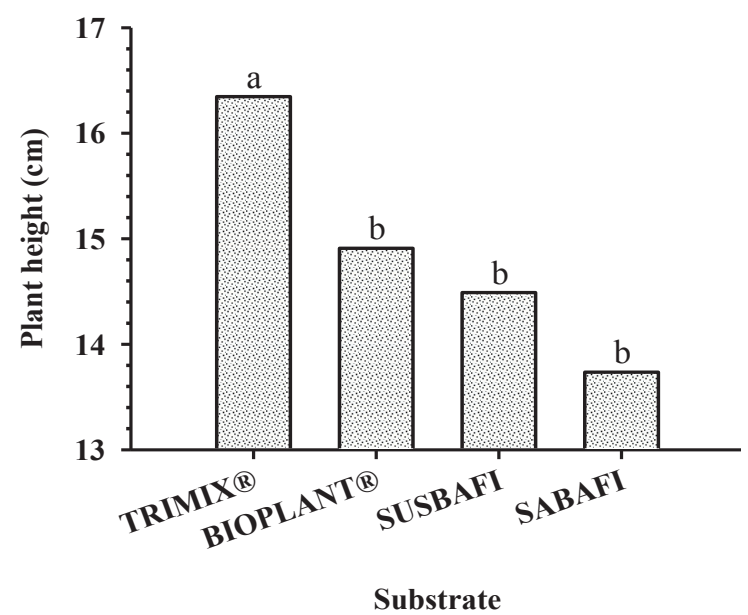

(e)

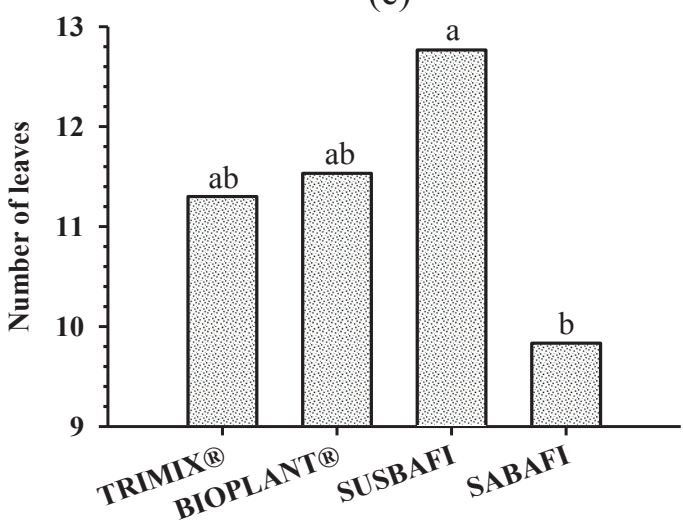

Substrate 
The DMR was the only variable with interaction between substrate and origin position, with higher results for TRIMIX ${ }^{\circledR}$ and SABAFI for bud chips of the base in relation to the apex (Figure $6 \mathrm{c}$ ) and, in general, the TRIMIX ${ }^{\circledR}$ substrate was better than the others, according to the statistical breakdown. This stresses the importance of the study of Gírio et al. (2015), where buds with greater organic reserves provided better results (Figure 5a).

Although the apical bud has a better physiological quality at the beginning, it is not the vigor that sustains the seedling during the production phase, but rather the organic reserve of the sett for its development and growth capacity. The general results of the productive variables suggest that this effect is suppressed during the PSS production process.

Evaluating the PSS (Figure 6), despite the performance inferior to that in TRIMIX ${ }^{\circledR}$ substrate, the use of by-products from the sugarcane industry as substrate in the PSS system demonstrated a satisfactory performance when associated with sand (SABAFI) or subsurface soil (SUSBAFI) and similar to the BIOPLANT ${ }^{\circledR}$ commercial substrate, the latter widely used in Brazilian horticulture, including the production of sugarcane PSS (OLIVEIRA et al., 2018). Thereby, it is necessary to carry out complementary studies aiming at the definition of formulations, chemical and physical-hydric characterization and performance of sugarcane in PSS, based on the use of sugarcane bagasse and filter cake as cultivation medium.

Although differences were detected in quality of seedlings produced in different substrates, it is necessary to evaluate their performance in sugarcane field conditions. This because the seedlings will be subjected to biotic and abiotic factors that may potentiate or even neutralize the effects obtained in nurseries. It is necessary, then, to conduct further field research evaluating the productivity and, especially, the longevity of sugarcane fields from PSS.

\section{Conclusions}

The substrates evaluated provided contrasting environments for root growth with respect to their physical-hydric and chemical attributes;

The use of by-products from the sugarcane industry in the formulation of substrates for the production of pre-sprouted sugarcane seedlings is possible, although the commercial substrate TRIMIX ${ }^{\circledR}$ presents superior performance, regardless of the position of the bub chip.

\section{Aknowledgements}

We would like to thank the Instituto Federal Goiano, for financial support, and the Usina Boa Vista for donation of bud chips used for the production of seedlings and of substrates residues.

\section{References}

ABAD, M.; MARTINEZ, P. F.; MARTINEZ, J. Evaluación agrónomica de los substratos de cultivo. Actas de Horticultura, Villaviciosa, v. 11, n. 1, p. 141154, 1993.

ALMEIDA JUNIOR, A. B.; NASCIMENTO, C. W. A.; SOBRAL, M. F.; SILVA, F. B. V.; GOMES, W. A. Fertilidade do solo e absorção de nutrientes em cana-deaçúcar fertilizada com torta de filtro. Revista Brasileira de Engenharia Agrícola e Ambiental, Campina Grande, v. 15, n. 10, p. 1004-1013, 2011.

BRASIL. Ministério da Agricultura, Pecuária e Abastecimento - MAPA. Secretaria de Defesa Agropecuária. Instrução Normativa $\mathrm{N}^{\circ} 17$, de 21 de maio de 2007. Aprova os métodos analíticos oficiais para análise de substratos e condicionadores de solos, na forma do Anexo à presente Instrução Normativa. Diário Oficial [da] República Federativa do Brasil, Brasília, 24 maio 2007. Seção 1, p. 8. Disponível em: <http://extranet. agricultura.gov.br/sislegis-consulta/consultarLegislacao. do? operacao $=$ visualizar\&id $=17762>$. Acessado em: 4 jan. 2016.

Secretaria de Defesa Agropecuária. Instrução Normativa N. ${ }^{\circ} 31$, de 23 de outubro de 2008. Altera os subitens 3.1.2, 4. 1 e 4. 1.2, do Anexo à Instrução Normativa SDA n. ${ }^{\circ} 17$, de 21 de maio de 2007. Diário Oficial [da] República Federativa do Brasil, Brasília, 24 
out. 2008. Seção 1, p. 20. Disponível em: <http://extranet. agricultura. gov.br/sislegis-consulta/consultarLegislacao. do? operacao $=$ visualizar\&id $=19154>$. Acesso em: 4 jan. 2016.

DE BOODT, M.; VERDONCK, O. The physical properties of the substrates in horticulture. Acta Horticulturae, Leuven, v. 26, n. 1, p. 37-44, 1972.

EMPRESA BRASILEIRA DE PESQUISA AGROPECUÁRIA - EMBRAPA. Manual de métodos de análise de solo. Rio de Janeiro: EMBRAPA Solos, 2011. $230 \mathrm{p}$.

FERMINO, M. H.; KÄMPF, A. N. Densidade de substratos dependendo dos métodos de análise e níveis de umidade. Horticultura Brasileira, Vitória da Conquista, v. 30, n. 1, p. 75-79, 2012.

FERRAZ, M. V.; CENTURION, J. F.; BEUTLER, A. N. Caracterização física e química de alguns substratos comerciais. Acta Scientiarum. Agronomy, Maringá, v. 27, n. 2, p. 209-214, 2005.

FERREIRA, D. F. Sisvar: a computer statistical analysis system. Ciência e Agrotecologia, Lavras, v. 35, n. 6, p. 1039-1042, 2011.

GÍRIO, L. A. S.; DIAS, F. L. F.; REIS, V. M.; URQUIAGA, S.; SCHULTZ, N.; BOLONHEZI, D.; MUTTON, M. A. Bactérias promotoras de crescimento e adubação nitrogenada no crescimento inicial de canade-açúcar proveniente de mudas pré-brotadas. Pesquisa Agropecuária Brasileira, Brasília, v. 50, n. 1, p. 33-43, 2015.

GONÇALVES, W. G.; SEVERIANO, E. C.; SILVA, F. G.; COSTA, K. A. P.; GUIMARÃES JÚNNYOR, W. S.; MELO, G. B. Least limiting water range in assessing compaction in a Brazilian Cerrado Latosol growing sugarcane. Revista Brasileira de Ciência do Solo, Viçosa, MG, v. 38, n. 2, p. 432-443, 2014.

KÄMPF, A. N. Seleção de materiais para uso como substrato. In: KÄMPF, A. N.; FERMINO, M. H. (Ed.). Substrato para plantas: a base da produção vegetal em recipientes. Porto Alegre: Gênesis, 2000. 312 p.

LANDELL, M. G. A.; CAMPANA, M. P.; FIGUEIREDO, P. Sistema de multiplicação de cana-de-açúcar com uso de mudas pré-brotadas (PSS), oriundas de gemas individualizadas. Campinas: Instituto Agronômico, 2012. 16 p. (Documentos IAC, n. 109).

LEMAIRE, F. Physical, chemical and biological properties of growing medium. Acta Horticulturae, Leuven, v. 396, n. 1, p. 273-284, 1995.

LUDWIG, F.; FERNANDES, D. M.; GUERRERO, A. C.; VILLAS BÔAS, R. L. Características dos substratos na absorção de nutrientes e na produção de gérbera de vaso. Horticultura Brasileira, Vitória da Conquista, v. 32, n. 2, p. 184-189, 2014.

MARTÍNEZ, P. F. Manejo de substratos para horticultura. In: FURLANI, A. M. C.; BATAGLIA, O. C.; ABREU, C. A.; ABREU, C. A.; FURLANI, P. R.; GUAGGIO, J. A.; MINAMI, K. (Coord.). Caracterização, manejo e qualidade de substratos para a produção de plantas. Campinas: Instituto Agronômico, 2002. 119 p. (Documentos IAC, n. 70).

NASCIMENTO, L. S.; NEVES, S. C. E.; CORRÊA, S. A. Utilização de bagaço de cana e torta de filtro como substrato orgânico para a produção de mudas de Eucalyptus. Revista Funec Científica-Multidisciplinar, Santa Fé do Sul, v. 2, n. 4, 2013.

NOGUEIRA, M. A. F. S.; GARCIA, M. S. Gestão dos resíduos do setor industrial sucroenergético: estudo de caso de uma usina no município de Rio Brilhante, Mato Grosso do Sul. Revista Eletrônica em Gestão, Educação e Tecnologia Ambiental - REGET, Santa Maria, v. 17, n. 17, p. 3275-3283, 2013.

OLIVEIRA, H. P.; MELO, R. O.; BALDOTTO, M. A.; ANDRADE, M. A.; BALDOTTO, L. E. B. Performance of pre-sprouted sugarcane seedlings in response to the application of humic acid and plant growth-promoting bacteria. Semina: Ciências Agrárias, Londrina, v. 39, n. 3, p. 1365-1370, 2018.

SANTANA, M. J.; CARVALHO, J. A.; SOUZA, K. J.; SOUSA, A. M. G.; VASCONCELOS, C. L.; ANDRADE, L. A. B. Efeitos da salinidade da água de irrigação na brotação e desenvolvimento inicial da cana-de-açúcar (Saccharum spp) e em solos com diferentes níveis texturais. Ciência e Agrotecnologia, Lavras, v. 31, n. 5, p. 1470-1476, 2007.

SEGATO, S. V.; MATTIUZ, C. F. M.; MOZAMBANI, A. E. Aspectos fenológicos da cana-de-açúcar. In: SEGATO, S. V.; PINTO, A. S.; JENDIROBA, E.; NÓBREGA, J. C. M. (Org.). Atualização em produção de cana-de-açúcar. Piracicaba: Livroceres, 2006. p. 19-36.

SEVERIANO, E. C.; OLIVEIRA, G. C.; DIAS JUNIOR, M. S.; CURI, N.; COSTA, K. A. P.; CARDUCCI, C. E. Preconsolidation pressure, soil water retention characteristics, and texture of Latosols in the Brazilian Cerrado. Soil Research, Melbourne, v. 51, n. 3, p. 193202, 2013.

UNIÃO DA INDÚSTRIA DE CANA-DE-AÇÚCAR. Produção de cana no Brasil. São Paulo: UNICADATA, 2018. Disponível em: <http://www.unica.com.br/ unicadata> . Acesso em: 12 maio 2018.

XAVIER, M. A.; LANDELL, M. G. A.; CAMPANA, M. 
P.; FIGUEIREDO, P.; MENDONÇA, J. R.; DINARDOMIRANDA, L. L.; SCARPARI, M. S.; GARCIA, J. C.; ANJOS, I. A.; AZANIA, C. A. M.; BRANCALIÃO, S. R.; KANTHACK, R. A. D.; AFERRI, G.; SILVA, D. N.; BIDÓIA, M. A. P.; CAMPOS, M. F.; PERRUCO, D.; MATSUO, R. S.; NEVES, J. C. T.; CASSANELI JUNIOR, J. R.; PERRUCO, L.; PETRI, R. H.; SILVA, T. N.; SILVA, V. H. P.; THOMAZINHO JUNIOR, J. R.; MIGUEL, P. E. M.; LORENZATO, C. M. Fatores de desuniformidade e kit de pré-brotação IAC para sistema de multiplicação de cana-de-açúcar - mudas prébrotadas (PSS). Campinas: Instituto Agronômico, 2014. 22 p. (Documentos IAC, n. 113).
ZANETTI, M.; FERNANDES, C.; CAZETTA, O. J.; CORÁ, J. E.; MATTOS JÚNIOR, D. Características físicas de substratos para produção de mudas cítricas sob telado. Laranja, Cordeirópolis, v. 24, n. 2, p. 507-518, 2003.

ZORZETO, T. Q.; DECHEN, S. C. F.; ABREU, M. F.; FERNANDES JÚNIOR, F. Caracterização física de substratos para plantas. Bragantia, Campinas, v. 73, n. 3 , p. $300-311,2014$. 
